\title{
2. ThE SECOND DEMOgRAPHIC TRANSITION IN EUROPE AND ITS IMPLICATIONS
}

\subsection{INTRODUCTION}

We, Europeans, perceive the world through the prism of what happens on our continent. Yet, it is important to remember that demographic changes, though possessing some similarities, may develop differently and have different consequences in other regions of the world. While population ageing is a universal phenomenon throughout the world, decreased population growth (or even negative growth as found in various European countries) is not common. According to UN prognoses, only 20\% of all world countries will record population decreases, $45 \%$ of which will be European countries. In general, the world population is to increase from the today's 7.08 billion (2012) to 9 billion by 2050 .

Even though demographic phenomena developed differently on specific continents, regions or countries, Europe has always been a continent where significant world population processes would start. One such process was the great emigration of Europeans in the 19th c. (it is estimated that between 1820 and 1914, 50-55 million Europeans left the continent). It is also widely agreed that it was Europe where the processes of the First and Second Demographic Transitions began. The first symptoms of the Second Transition were observed in Denmark, the Netherlands, and Belgium. Subject literature also mentions the beginning of demographic changes in the European continent which are referred to as the Third Demographic Transition.

The 20th c., particularly its second half, was a period of profound political, economic and social changes throughout the world. They largely determined the ongoing at that time demographic processes which in turn influenced the above- 
-mentioned groups of changes. Europe was also a continent which experienced many political and economic changes in the previous century, particularly in its second half, which influenced to a large extent or even determined population changes. Those events spurred socio-cultural and civilisational changes. One of the most important changes was the erosion of traditional values, including a fundamental transformation of the system of values. New behaviours and attitudes were a result of the experiences of WWII and the loss of faith in the civilisational mission of Europe. The atrocities of totalitarian ideologies and the failure to construct a better world order were also a significant factor in socio-cultural changes. They resulted in a return to individualistic thinking where people have only one life and it is worth living it according to ones own choices (Okólski 2004).

In this article, I would like to present selected demographic changes in European countries related to the Second Demographic Transition. I will present selected demographic specifications of European countries and their spatial diversity. Considering selected quantitative indicators, I compared the courses of demographic changes in European countries according to long-term political division of Europe into Eastern and Western Europe.

\subsection{THE THEORY OF THE SECOND DEMOGRAPHIC TRANSITION}

The Second Demographic Transition is the most popular theory explaining the changes within the areas of nuptiality and reproduction. Van de Kaa and Leasthaege, its authors, claim that Europe was the first continent to enter the new phase of demographic development. The theory of the Second Demographic Transition constitutes a method of describing, interpreting and explicating demographic changes in European countries with developed market economies. It is considered that the changes began in late 1950s or in the first half of the 1960s (Okólski 2005).

However, the course of the Second Transition processes was not identical in specific European countries and their intensity was different as well. They started in Scandinavia in 1950s and spread to the countries of Western Europe in the 1960s and of Southern Europe in the 1970s. Observations of those tendencies enabled researchers to identify three sub-periods of demographic changes:

- the 1955-1970 period which witnessed an increased rise in the number of divorces, further decline of fertility and a slowing of the decrease of the age of entering into first marriage,

- the 1970-1985 period was a time when consensual and Living-Apart-Together relationships were becoming common, the number of out-of-wedlock births increased, the age of the mother giving birth to her first child rose, the 
average age of spouses rose, and the frequency of entering into marriage dropped,

- since 1985, researchers have been observing a stabilization of divorce intensity, a drop in the frequency of remarriages and an increase in the intensity of cohabitations and LAT-type relationships among divorced people or widows/widowers, a further drop in fertility among the youngest age group (1524) and an increase of fertility among women aged 30-39 (Lesthaeghe 1991 in: Kotowska 1998).

The Second Demographic Transition covers the following changes related to the model of the family and the principles of creating and dissolving it:

1. A decline of the significance of marriage as a form of people's coexistence in favour of cohabitation,

2. A transition from the king-child with parents model of the family to the king-pair with a child model,

3. A transition from preventive contraception to aware procreation,

4. A transition from homogeneous family types and households to forms of diversity.

Within those changes, van de Kaa introduced a sequence of demographic changes which occurred in 1965-1995 in the countries of Northern and Western Europe. Those include the following facts:

- a drop in general fertility rate resulting from a decrease in fertility of older age groups, a drop in the higher order birth rate,

- a drop in premarital pregnancies and pregnancy-induced marriages,

- delay in child birth in married couples, a drop in young women's fertility, a decrease in the lower order birth rate,

- an increase in the number of separations and divorces,

- a delay in entering into marriage coexists with an even more common pre-marital cohabitation, an increase in the average age of entering into first marriage,

- pre-marital cohabitations and delaying the decision to enter into marriage until the woman becomes pregnant are becoming more common, and there is an increase in the number of out-of-wedlock births,

- an increase of the average age of giving birth to the first child,

- further drop in the number of unintended births as a result of legalisation of sterilisation and abortion, continued decrease in fertility in the youngest and the oldest age groups,

- an increase of social acceptance of cohabitation which even more often applies to divorced people or widows/widowers,

- viewing cohabitation as an alternative to marriage, further increase of non-marital fertility,

- stabilisation of the general fertility rate at a low level, 
- a slight increase in the general fertility rate as a result of the emergence of delayed births, increased lower order birth rate among older women,

- not all delayed births may be fulfilled by women of older reproductive age groups,

- increasing scope of voluntary childlessness,

- stabilisation of cohort fertility below simple demographic renewal (van de Kaa 1987 in: Kotowska 1998).

The process of the Second Demographic Transition began in the most economically developed countries. Its was mainly a result of widely understood modernisation of the society which researchers analyse from several dimensions, i.e. economic, cultural and awareness-mental dimension. The shift from materialistic to post-modern values focused on individualism was an element which influenced the change of the hierarchy of values related to the family. Social and socio-economic structure changes, e.g. industrialisation, urban development or tertiarisation of economy served as the foundation of modernisation. Structural changes also applied to the areas of political, world-view and information life. Those changes included the strengthening of democracy, egalitarianism, increased autonomy of the individual, secularisation, the development of medicine, the second contraceptive revolution, the evolution of telecommunications and globalisation of information.

The processes of demographic changes which began in the north and west of Europe in the 1990s have spread onto Central and Eastern Europe. The differences between Western and Eastern Europe as divided by the Hajnal line are fading, today researchers refer to a new spatial division of European countries based on demographic behaviours. The line drawn by Hajnal in the 1960s divided Europe along the St. Petersburg - Trieste line into the European section (European model) and the East European section (East European model). This division applied to the model of entering into marriage which was observed since the beginning of the 18th c. all the way to mid-20th c. Eastern Europe displayed a dominance of early marriages whereas in the European model, the decision to enter into marriage was often postponed or marriage was avoided altogether (Table 1).

The dichotomous division of Europe related to the political division began to disappear in the late-1980s when the transformation of the Communist Bloc began. It was one of the reasons of the profound demographic changes which additionally occurred within a very short period of time. Their speed was so high that it resulted in depopulation of many countries. 
The percentage of single men and women in selected age groups in 1900 (per 100 people in each age and sex group)

\begin{tabular}{|l|c|c|c|c|c|c|}
\hline \multirow{2}{*}{ Country } & \multicolumn{5}{|c|}{ Men } & \multicolumn{3}{c|}{ Women } \\
\cline { 2 - 7 } & $20-24$ & $25-29$ & $45-49$ & $20-24$ & $25-29$ & $45-49$ \\
\hline \multicolumn{7}{|c|}{ European model } \\
\hline Belgium & 85 & 50 & 16 & 71 & 41 & 17 \\
\hline France & 90 & 48 & 11 & 58 & 30 & 12 \\
\hline Sweden & 92 & 61 & 13 & 80 & 52 & 19 \\
\hline \multicolumn{7}{|c|}{ East European model } \\
\hline $\begin{array}{l}\text { Greece } \\
\text { (transitional model) }\end{array}$ & 82 & 47 & 9 & 44 & 13 & 4 \\
\hline Bulgaria & 58 & 9 & 3 & 24 & 3 & 1 \\
\hline Serbia & 50 & 23 & 3 & 16 & 2 & 1 \\
\hline
\end{tabular}

Source: Hajnal (1965) in: J. Kurkiewicz (1998).

\subsection{THE SIZE OF THE EUROPEAN POPULATION ${ }^{1}$ AND ITS CHANGES}

To understand the causes of the current demographic situation of European societies better, it is necessary to define the significance of World War II. Its influence on the formation of reproduction attitudes of contemporary Europeans was very high and its consequences have been observed since its end 60 years ago. In physical terms, WWII caused a great decrease of population among the most important age groups. Additionally, most European countries inflicted by

${ }^{1}$ Population analyses regarding European countries require a further specification of the distribution of the borderline between Europe and Asia and, subsequently, which countries are considered as European. The geographical borderline introduced by the International Geographical Union has the following distribution: from the Kerch Strait northward, along the east coast of the Sea of Azov, to the estuary of the Don; further, up the river to Sostynskiye Lakes and the location where the Manych flows into them; then, along the Kuma-Manych Depression to the middle section of the Kuma; then, along its lower section eastward to the estuary to the Caspian Sea; further, along the north-western and northern coast of the reservoir to the (seasonal) estuary of the Emba River; then, up the Emba River north-eastward to its source in Mugodzhar Hills; further, perpendicularly northward to the location where the Ural takes a sharp turn west and along its upper section to the foot of the Ural Mountains (this is the distribution most commonly referred to by Polish geographers); finally, along the eastern foot of the mountains northward to the Baydarata, along which it turns north-east to its estuary to Baydaratskaya Bay on the Kara Sea (the Arctic Ocean). 
the war recorded a drastic drop in fertility. That was the case because in unfavourable wartime conditions people refrained from having children ${ }^{2}$. However, the population of Europe was able to quickly compensate for the physical wartime losses, yet, a slightly different threat arose as the war ended. Around 1950, the process of the Demographic Transition in Europe was coming to an end. Apart from the final post-war wave of births, mortality and fertility rates were clearly balanced within their lower values. However, already in the first half of the 1960s, nearly all Western and Northern European countries recorded a sharp decrease of fertility. This unexpected situation became a constant phenomenon throughout Europe (Siewierski 2011). Regardless of the decrease of fertility, the population of Europe has been gradually growing since the 1960s reaching 739 million in 2011. Only Eastern European countries ${ }^{3}$ have shown negative population growth since the beginning of the new century (Table 2). Considering the population changes in European countries, it should be noted that the countries of Central and Eastern Europe and the Balkans are depopulating (Fig. 1, Table 3). The largest depopulation between 2003-2012 was recorded in Lithuania (13.1\%), Latvia (12.4\%), Bosnia and Herzegovina (9.3\%) and Albania (8.7\%). Since 2002, this group was joined by Germany which within the period of 2003-2011 recorded a decrease of population by nearly 693,000 which constituted almost $1 \%$ of its population potential in 2003 (Auszug aus dem Datenreport 2011. Bevölkerung, www.destatis.de/DE/Publikationen/ Datenreport/ Datenreport Download.html).

Table 2

Population of Europe ${ }^{\mathrm{a}}$ in 1960-2011

\begin{tabular}{|l|r|r|r|r|r|r|r|}
\hline \multirow{2}{*}{ Distinction } & \multicolumn{7}{|c|}{ Year } \\
\cline { 2 - 8 } & 1960 & 1970 & 1980 & 1990 & 2000 & 2010 & 2011 \\
\hline Europe & 603.9 & 655.9 & 692.9 & 720.5 & 726.8 & 738.2 & 739.3 \\
\hline Eastern & 252.8 & 276.2 & 294.9 & 310.5 & 304.2 & 294.8 & 294.3 \\
\hline Northern & 81.9 & 87.4 & 89.9 & 92.1 & 94.3 & 99.2 & 99.8 \\
\hline Southern & 117.4 & 126.8 & 137.7 & 142.4 & 145.1 & 155.2 & 155.8 \\
\hline Western & 151.8 & 165.5 & 170.4 & 175.4 & 183.1 & 189.1 & 189.4 \\
\hline
\end{tabular}

Note: a - without Turkey which is considered as Western Asia.

Source: Yearbook Demographic 2011, (2012).

${ }^{2}$ According to the theory of the principles of was by Rosset (Rosset 1975).

${ }^{3}$ UN division into regions: Eastern, Western, Northern and Southern Europe. 


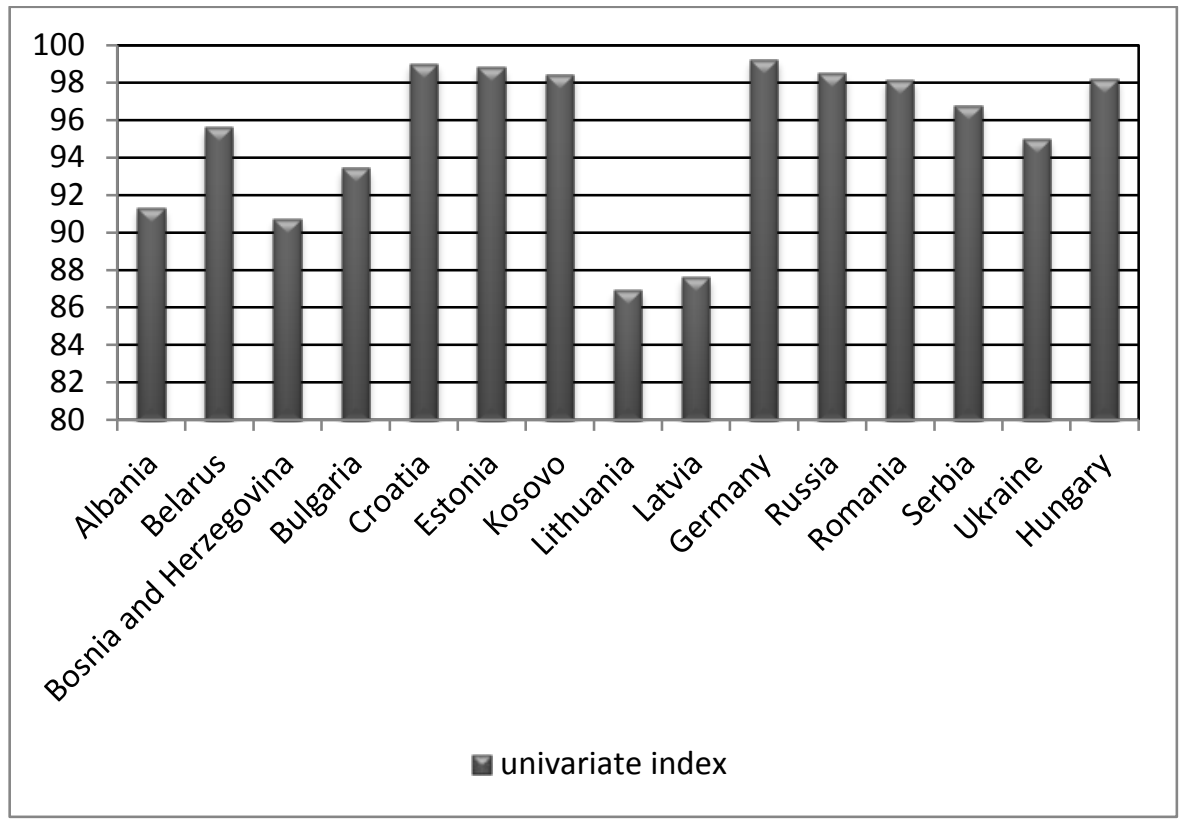

Note: data for Albania from 2011.

Fig. 1. European countries experiencing depopulation processes in 2003-2012 according to univariate index

Source: Eurostat, http://epp.eurostat.ec.europa.eu/portal/page/portal/population/ data/database

The decrease of the populations of European countries is usually a combination of both elements determining actual population growth, i.e. negative population growth rate and migration balance. Among 15 studied countries which recorded a decrease of population potential, only two displayed positive population growths: Albania and Kosovo ${ }^{4}$. In the remaining ones, population loss spanned from $-0.8 \%$ in Bosnia and Herzegovina to $-5.1 \%$ in Bulgaria and Serbia (Fig. 2). In the case of Kosovo and Albania, population loss was a result of migration. Particularly Albania is a country where mass

\footnotetext{
${ }^{4}$ Kosovo declared its independence on 17 February 2008 as the Republic of Kosovo. It was recognised by 100 out of 193 UN members, 22 out of 27 EU Member States and 24 out of 28 NATO members, however, formally, it is a state with limited recognition. Since the end of the civil war, it was placed under transitional UN administration (the United Nations Interim Administration Mission in Kosovo, or UNMIK) with the support of NATO troops (KFOR). I decided to include Kosovo in my study regardless of its recognition under international law. I did this to offer the most comprehensive demographic overview of Europe.
} 
Table 3

European countries experiencing depopulation processes in 2003-2012

\begin{tabular}{|l|c|c|c|c|}
\hline \multicolumn{1}{|c|}{ Country } & $\begin{array}{c}\text { Population } \\
\text { in 2003 }\end{array}$ & $\begin{array}{c}\text { Population } \\
\text { in 2012 }\end{array}$ & $\begin{array}{c}\text { Actual } \\
\text { population loss }\end{array}$ & Loss in \% \\
\hline Albania $^{\mathrm{a}}$ & $3,102,781$ & $2,831,741$ & 271,040 & 8.7 \\
\hline Belarus & $9,898,590$ & $9,465,150$ & 433,440 & 4.4 \\
\hline $\begin{array}{l}\text { Bosnia and } \\
\text { Herzegovina }\end{array}$ & $1,985,000$ & $1,800,000$ & 185,000 & 9.3 \\
\hline Bulgaria & $7,845,841$ & $7,327,224$ & 518,617 & 6.6 \\
\hline Croatia & $1,356,045$ & $4,398,150$ & 44,594 & 1.0 \\
\hline Estonia & $1,356,045$ & $1,356,045$ & 16,383 & 1.2 \\
\hline Kosovo & $3,618,312$ & $3,559,541$ & 58,771 & 1.6 \\
\hline Lithuania & $3,462,553$ & $3,007,758$ & 454,795 & 13.1 \\
\hline Latvia & $2,331,480$ & $2,041,763$ & 289,717 & 12.4 \\
\hline Germany & $82,536,680$ & $82,536,680$ & 692,937 & 0.8 \\
\hline Russia & $145,166,731$ & $143,056,383$ & $2,110,348$ & 1.5 \\
\hline Romania & $21,772,774$ & $21,355,849$ & 416,925 & 1.9 \\
\hline Serbia & $7,490,918$ & $7,241,295$ & 249,623 & 3.3 \\
\hline Ukraine & $47,823,108$ & $45,453,282$ & $2,369,826$ & 5.0 \\
\hline Hungary & $10,142,362$ & $9,957,731$ & 184,631 & 1.8 \\
\hline
\end{tabular}

Note: data from 2011.

Source: Eurostat, http://epp.eurostat.ec.europa.eu/portal/page/portal/population/data/ database.

migrations to Italy and Greece have been recorded since early 1990s. According to the data offered by INSTAT (Albanian Institute of Statistics), over 1 million people have left the country since the fall of communism in $1991^{5}$. Depopulation processes in several other European countries are magnified by both, high negative values of population growth and foreign migration balance. Those are the reasons of such a high relative population loss in, e.g. the Baltic states. In the remaining European countries, population is growing and population growth rate is negative only in Italy $(-0.6 \%)$, Portugal $(-0.6 \%)$ and Greece $(-0.4 \%$ o). According to data by EU Statistical Office, the highest population growth rate in 2011 was recorded in Azerbaijan ${ }^{6}$ (13.4\%o), Turkey (12.3\%o), Kosovo (11.4\%o) and Ireland (10.0\%o).

\footnotetext{
${ }^{5}$ Via Polish Press Agency which released the data on 30.12.2011.

${ }^{6}$ According to UN statistics, Turkey, Cyprus, Armenia, Azerbaijan, and Georgia are considered as Asian countries; Eurostat considers them as European countries.
} 

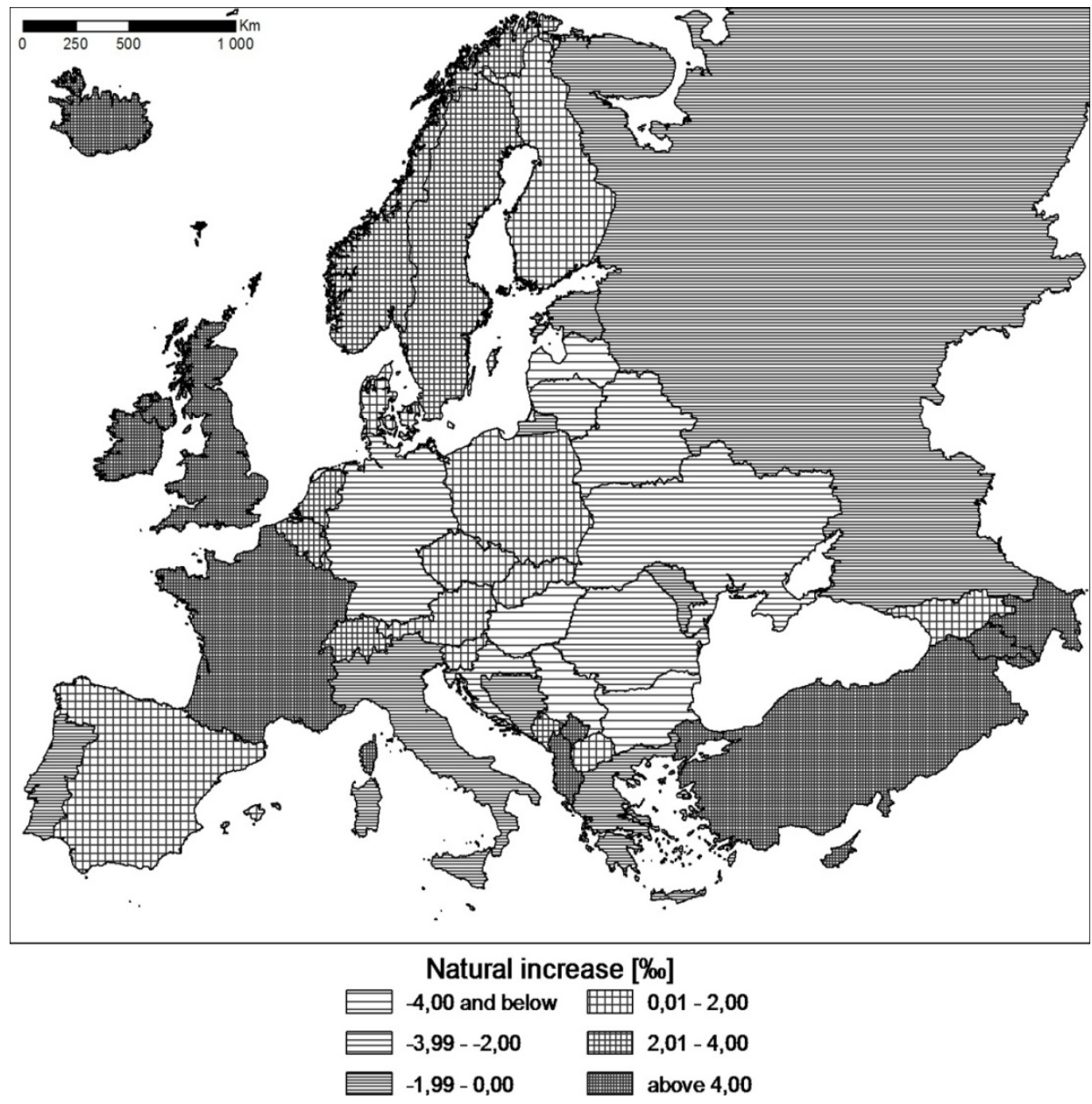

Fig. 2. Natural increase in European countries in 2011

Source: Source: Eurostat, http://epp.eurostat.ec.europa.eu/portal/page/portal/ population/data/database

The UN demographic prognoses regarding the future of the European continent are bleak. The moderate variant forecasts the population of Europe will decrease between 2020 and 2090 - by more than 90 million (with a slight increase in the final decade). The largest depopulation is expected to hit Eastern and Southern Europe, the remaining European countries (excluding Germany decrease by more than 11 million) are to record an increase of their populations (Fig. 3). 


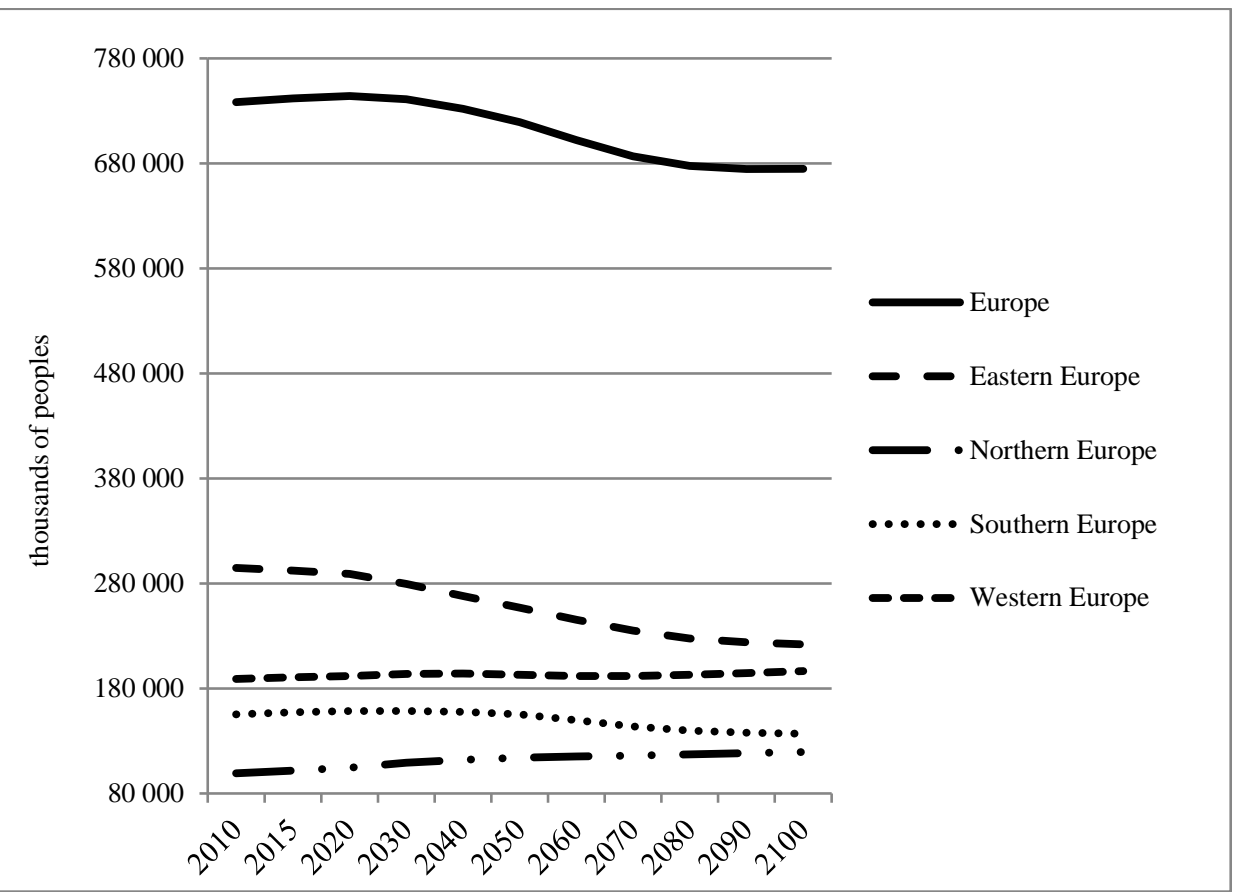

Fig. 3. Moderate variant of the demographic prognosis for Europe by 2100 Source: World Population Prospect. The 2010 Revision (2011)

\subsection{BEHAVIOURS IN THE FIELDS OF NUPTIALITY AND REPRODUCTION IN EUROPEAN COUNTRIES}

Matrimonial changes, according to the theory of the Second Demographic Transition, are related to the model of family formation and breakdown. Even though the processes of the Second Demographic Transition began with a large drop in fertility, matrimonial behaviours as initial elements of people's reproductive process constitute an important factor of those changes. Particularly when a bleak prospect of depopulation and demographic crisis approaches Europe, demographic analyses of family formation and breakdown become especially significant.

I conducted the analysis of matrimonial behaviours in European countries based on available information regarding entering into marriage, its breakdown and alternative forms of married and family life. To enter into marriage, a person must not only display physical, but also emotional and social maturity. Thus, lawmakers in individual countries define minimum legal ages for entering into marriage. In European countries, the age limit for entering into marriage is 
similar, i.e. 18 years of age, but there are some exceptions regarding marrying with parental consent. In most European countries which offer such an exception, the age limit is 16; in Denmark, Estonia, Slovenia, Ukraine and Lithuania, one may marry with parental consent at the age of 15, while in Spain - at the age of 14. In some countries, the age limit may be lowered by the court (e.g. in Austria) or by the Ministry of Justice (e.g. in Finland) - Yearbook Demographic 2011 (2012). In Poland, pursuant to an amendment to the Family and Guardship Code of 1999, juvenile marriages are formed if allowed by the family court only if the marriage is entered into by a minor woman aged 16-17 (Art. 10).

In a report The Evolution of Family in Europe 2009, the EU Institute for Family Policy concluded that since 1980, European countries (27 EU member states were analysed) have been recording drastic decreases of new marriages even though the total population increased by more than 42 million. Between 1980-2007, the number of new marriage decreased by 750,000 (23.4\%) and the marriage ratio dropped from 6.75\% (1980) to 4.87\%o (2007). Only two countries, Denmark and Sweden, recorded an increase of new marriages (in terms of absolute values, while the marriage ratio fluctuated and decreased by the end of the period), while the worst situation was recorded in Bulgaria, Slovenia and Estonia where the values dropped by nearly 50\%. When considering an even longer time perspective, i.e. 1960-2011, the systematic continuation of the downward tendency of the marriage ratio in European countries (both EU member states and non-member states) is visible. The lowest values of the marriage ratio in 2011 were recorded in Bulgaria (2.9\%), Andorra (3.1\%o), Slovenia (3.2\%o) and Luxembourg (3.3\%o), while the highest in Turkey $(8.0 \%)$, Macedonia (7.3\%) and Cyprus (7.2\%). Poland with the ratio of 5.4\%o falls within the group of the European countries with average values - cf. Fig. 4.

The downward tendency of new marriages in European countries is accompanied by an increase of the number of divorces as described by T. Sobotka and L. Touleman (2008). The above-mentioned Evolution of Family in Europe in 2009 report states that in EU in 1980, nearly 673,000 divorces were adjudicated, while in 2007, the value increased to 1.03 million. Between 1997-2007, 10.3 million marriages, which were raising more than 17 million children, suffered a breakdown. In early 1960s, the divorce rates in Europe varied between $0.3 \%$ in Greece to $2.4 \%$ in Latvia, while fifty years later $-0.1 \%$ in Malta to 4\% in Latvia (Fig. 5). In most European countries, the divorce ratio within that period increased by several times (e.g. in Belgium from 0.5 to $2.9 \%$, in Lithuania from 0.9 to $3.4 \%$, in Poland from 0.5 to $1.7 \%$ ). 


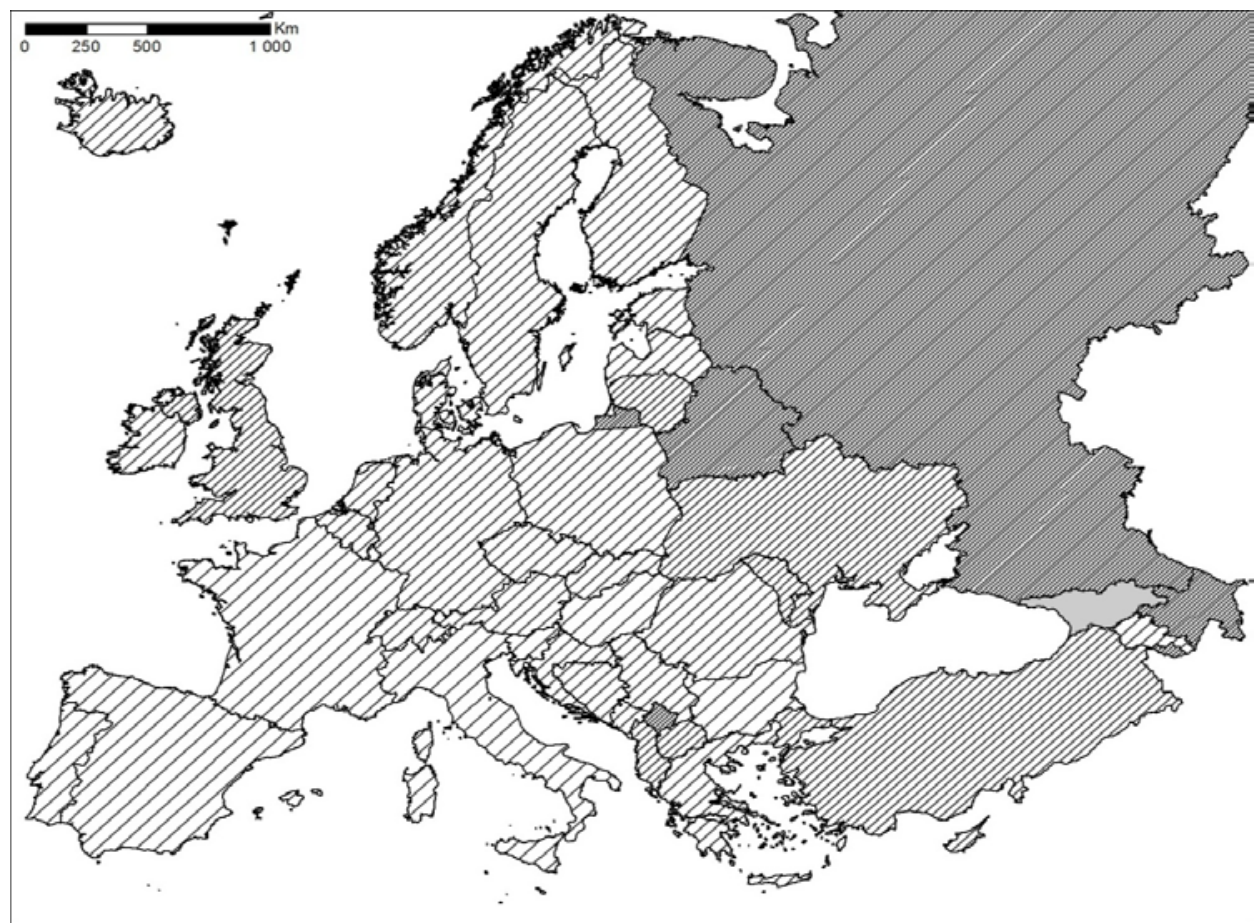

\section{Crude marriage rate $[\%$ ]}

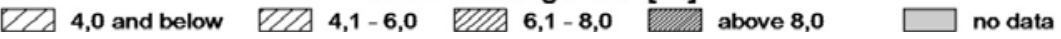

Fig. 4. Marriage ratio in European countries in 2011

Source: Eurostat, http://epp.eurostat.ec.europa.eu/portal/page/portal/ population/ data/database

One of the symptoms of the Second Demographic Transition is a decline of the significance of marriage as a form of people's coexistence in favour of cohabitation. The downward tendency of new marriages is accompanied by the increasing popularity of alternative forms of living, i.e. informal relationships. New legal regulations are introduced in many countries with the appearance of new behaviours and demographic attitudes in nuptiality. One could even argue that there is a worldwide tendency to place non-marital relationships, including homosexual relationships, into legal frameworks. In the case of the latter, it need be stressed that since 1989, may countries have introduced options to formalise relationships formed by same-sex couples into their law. European countries which decided to introduce new legal solutions or legitimize the existence of such relationships through court ruling include: Andorra, Austria, Belgium, Croatia, the Czech Republic, Denmark, Finland, France, Spain, the Netherlands, Ireland, Iceland, Liechtenstein, Luxembourg, Germany, Norway, Portugal, 


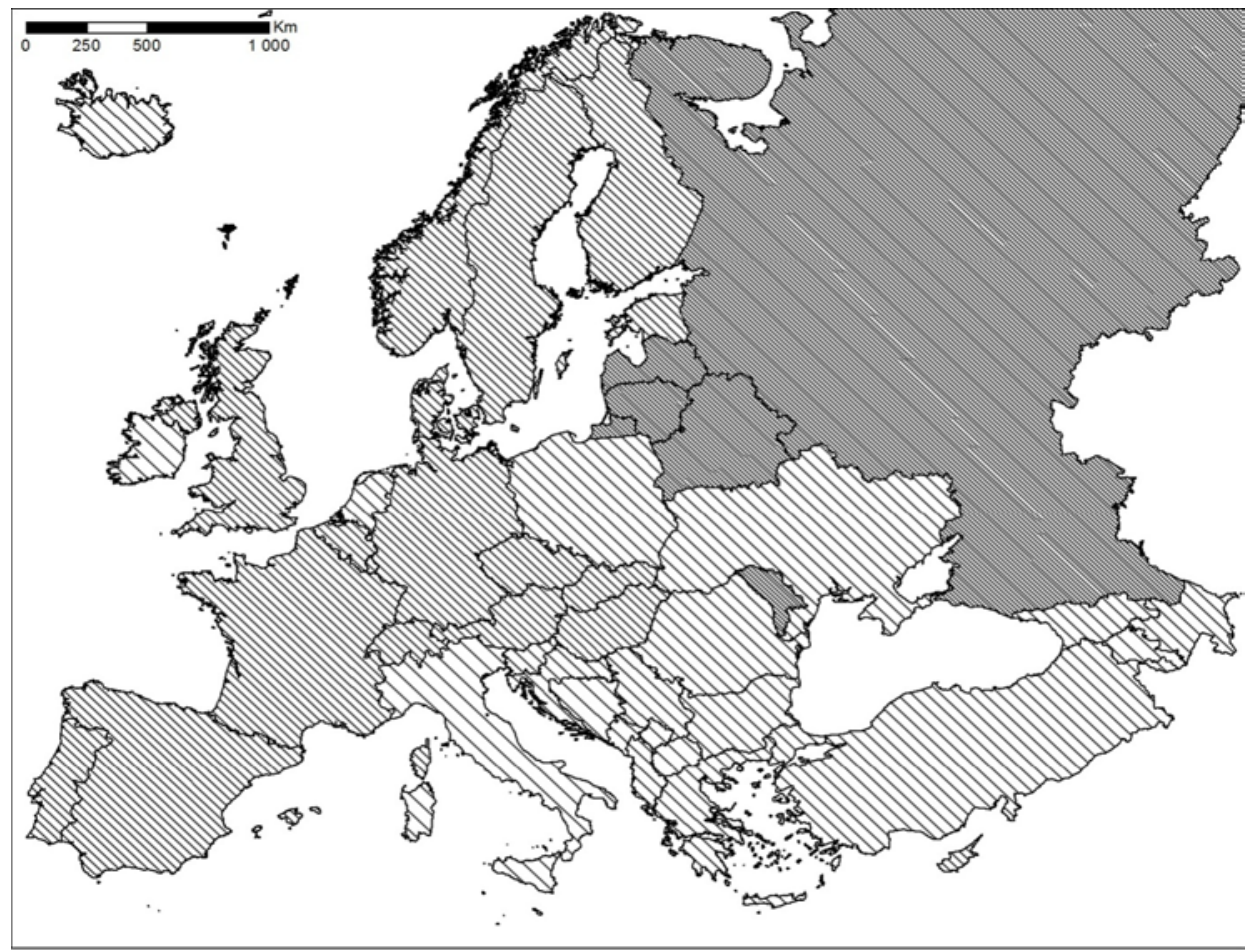

Crude divorce rate [\%]

1,0 and below $\mathbb{N V}$ 1,1-2,0 $\mathbb{N}$ 2,1-3,0 $\mathbb{R}$ above 3,0

Fig. 5. Divorces ratio in European countries in 2011

Source: Eurostat, http://epp.eurostat.ec.europa.eu/portal/page/portal/population/ data/database

Slovenia, Switzerland, Sweden, Hungary, the United Kingdom. The first country to introduce civil partnerships was Denmark in 1989. It must be stated that currently the majority of EU Member States (including some states which joined the EU together with Poland in 2004) introduced regulations enabling the formalisation of partnership of people of the same sex. Institutionalisation of same-sex relationships in those countries varies in form depending on the will of national lawmakers. There are four forms of regulating the functioning of such relationships:

1. Marriage,

2. Civil partnership,

3. Registered cohabitation,

4. Non-registered cohabitation.

Marriage - within the scope available for heterosexual couples - is available (open) as a legal institution to same-sex couples in ten European countries: Belgium, Denmark, Spain, the Netherlands, Iceland, Norway, Portugal, Sweden 
and most recently France and the United Kingdom. The option for same-sex couples to marry was introduced, depending on the country, either through expanding the scope of entities entitled to this form of relationship institutionalisation in specific legal acts (e.g. civil codes, family codes etc.) or through passing special separate legal acts regulating the functioning of such marriages. It is worth noticing that, regardless of the method of introducing the above-mentioned institution, the discussed countries did not create a separate institution of "same-sex marriages" or "homosexual marriages". What did change was the group of entities entitled to utilize it.

Another form of institutionalisation of same-sex relationships which was implemented by many foreign lawmakers is civil partnership, also known as registered partnership. This was introduced, e.g. in the Czech Republic, Ireland, Germany, Hungary and the United Kingdom. Registered partnership is formed through an official registration act and entails a specific set of rights and responsibilities as specified by certain acts, usually excluding parental rights. Such a solution seems to be a compromise between respecting the rights of people living in same-sex relationships and such considerations as, e.g. the constitutional definition of marriage which excludes same-sex marriages. The institution of civil partnership usually regulates basic organisational issues, such as filing tax returns, retirement, insurance, disability benefits and inheritance, lease, residency in a given country or the ability to establish joint property. In the countries which decided to regulate same-sex relationships, this form is much more popular than marriage. Apart from civil partnerships, there is the institution of registered cohabitation, offering a narrower scope of rights and responsibilities than the above-mentioned forms of institutionalisation. A characteristic feature of this form of relationship is that there is no change to the marital status of the persons forming it. Nonetheless, this type of cohabitation not only carries some rights and responsibilities often regulated through a single legal act but also, to be recognised legally, must be revealed and registered by the state. A special case, between registered partnership and registered cohabitant, is the French solution of Pacte civil de solidarité (PACS). It is a civil law agreement which is available to both same-sex and heterosexual couples. Most rights related to PACS apply to property and social issues. What is characteristic of it is that, unlike in the case of marriage or civil partnership, in PACS mutual responsibilities and rights of partners are defined by themselves and not by lawmakers who only created a list of rights and responsibilities towards third parties. It differs from other registered cohabitations in that mutual rights and responsibilities of partners are written down, thus, they are clearly defined and not flexible or vague. The PACS act consists of 15 articles and, unlike in the case of acts introducing civil partnerships which comprehensively regulate the institution within a single legal act, constitutes an amendment to 
several legal acts, including the French civil code, tax code, social security code, the regulations regarding the functioning of state and local public authorities, leasing apartments, labour code provisions and the regulations regarding residency in France.

Non-registered cohabitation is the simplest form of legal approach towards the union of two people. It is a set of factual circumstances defined by lawmakers or in specific decisions and literature which entails through the application of legal acts, usually scattered among various legal acts, certain legal consequences - responsibilities, rights but often also some restrictions. For same-sex couples, this solution can be available either if lawmakers enable it (e.g. in Hungary or Croatia) or on the basis of coherent interpretation of regulations. In Poland, cohabitation, referred to as joint living (in some legal acts - "actual joint living”), covers only heterosexual couples (MP's civil partnership bill, document no. 552, http://www.sejm.gov.pl/Sejm7.nsf/druki.xsp\#7).

In Poland, there were also initiatives to legalise solutions which would guarantee the formalisation of civil partnerships. In January 2012 during a conference in the Sejm, representatives of Palikot's Movement, Democratic Left Alliance, Trans-Fuzja, Civil Partnership Initiative Group and Love Does Not Exclude groups informed that in the near future, two bills will be filed with the Sejm - regarding civil partnership agreements and the institution of civil partnership. Civic Platform also filed a bill. However, on 25 January 2013, the Sejm rejected the civil partnership bill. The bills by PO, SLD and Palikot's Movement also failed. A motion filed by Artur Dunin, MP (PO) was the nearest to being successful. His proposal included, e.g. the option to register civil partnerships at the Registry of Vital Records and Statistics, the introduction of statutory inheriting and the obligation to mutual care, entitlement to obtain information regarding partner's health when he/she is at the hospital and the right to refrain from giving testimony against one's partner. SLD and RP went a step further proposing a joint tax return option. All bills applied to not only homosexual couples whose rights were discussed the most, but also heterosexual couples. None of the bills offered an opportunity to adopt a child by civil partnerships.

The above-mentioned tendencies related to nuptiality are reflected in the population structure according to marital status. Using Eurostat data ${ }^{7}$ for selected 22 European countries, one will notice that the highest share of divorcees is found in Central and Eastern European countries (Latvia, the Czech Republic, Lithuania and Hungary). Similarly, the percentages of married people in those countries are some of the lowest in Europe. Unfortunately, statistical information regarding people in registered partnerships is scarce; however, it

${ }^{7}$ In the table with marital status information, the data applies to entire populations, in Poland, legal marital status is specified for people aged 15 or more. 
does indicate that the highest share of people of this marital status exists in Iceland

(Table

4).

Even though Poland does not possess any legal solutions defining the registration of civil partnerships, the last two censuses did measure the size of the phenomenon. Their results showed that the share of people living in civil partnerships in our country increased from 1.3\% in 2002 to $2.4 \%$ in 2011.

Table 4

Marital status of the citizens of selected European countries in 2012

\begin{tabular}{|c|c|c|c|c|}
\hline \multirow[b]{2}{*}{ Country } & \multicolumn{4}{|c|}{ Share of people ${ }^{\mathrm{a}}(\%)$ who are } \\
\hline & single $^{b}$ & married & divorced & $\begin{array}{c}\text { in a registered } \\
\text { partnership }\end{array}$ \\
\hline Denmark & 44.37 & 40.21 & 8.40 & . \\
\hline $\begin{array}{l}\text { the Czech } \\
\text { Republic }\end{array}$ & 40.23 & 41.98 & 10.53 & . \\
\hline Denmark & 47.30 & 38.87 & 8.21 & 0.16 \\
\hline Germany & 42.30 & 42.41 & 8.15 & . \\
\hline France & 49.60 & 37.48 & 6.46 & . \\
\hline Italy & 41.48 & 49.00 & & - \\
\hline Latvia & 41.41 & 37.24 & 12.36 & - \\
\hline Lithuania & 41.44 & 40.94 & 10.00 & - \\
\hline Hungary & 43.17 & 37.87 & 9.46 & 0.004 \\
\hline Malta & 43.12 & 49.70 & 0.24 & . \\
\hline the Netherlands & 46.87 & 40.18 & 7.01 & 0.773 \\
\hline Romania & 37.97 & 49.51 & 4.73 & - \\
\hline Slovenia & 47.72 & 39.62 & 5.60 & - \\
\hline Slovakia & 43.26 & 43.74 & 6.68 & - \\
\hline Finland & 47.47 & 37.26 & 9.78 & 0.076 \\
\hline Sweden & 51.62 & 33.86 & 9.55 & 0.036 \\
\hline Iceland & 43.29 & 33.83 & 5.26 & 8.114 \\
\hline Liechtenstein & 42.91 & 45.07 & 7.25 & 0.049 \\
\hline Norway & 50.96 & 35.22 & 7.64 & \\
\hline Switzerland & 43.15 & 43.81 & 7.77 & 0.125 \\
\hline Turkey & 45.70 & 47.73 & 2.24 & - \\
\hline Azerbaijan & 45.86 & 47.41 & 1.43 & - \\
\hline
\end{tabular}

Note: ${ }^{\mathrm{a}}$ - share calculated in relation to total population; ${ }^{\mathrm{b}}$ - Eurostat considers all people who not in any relationship regardless of their age as single.

Source: Eurostat, http://epp.eurostat.ec.europa.eu/portal/page/portal/population/data/ database. 
Until recently, reproductive behaviours were strictly connected with matrimonial behaviours. The relationship between the number of new marriages and the number of birth, both potential and actual, was high. The changes related to the Second Demographic Transition also influenced reproductive behaviours by increasing the share of non-marital births, including in civil partnerships and by single mothers. At the beginning of the transition (1960s), non-marital births constituted between a few to a dozen or so percent of all births (Iceland was an exception with 25.3\%). Today, in many European countries, more than half of all the children are born outside of marriage. This also applies to Central and Eastern European countries but Iceland is still the leader (65\%). Only countries where religious values still play an important role and the level of secularisation of the society is low record low share of non-marital births, e.g. Turkey, Greece, Poland (Fig. 6).

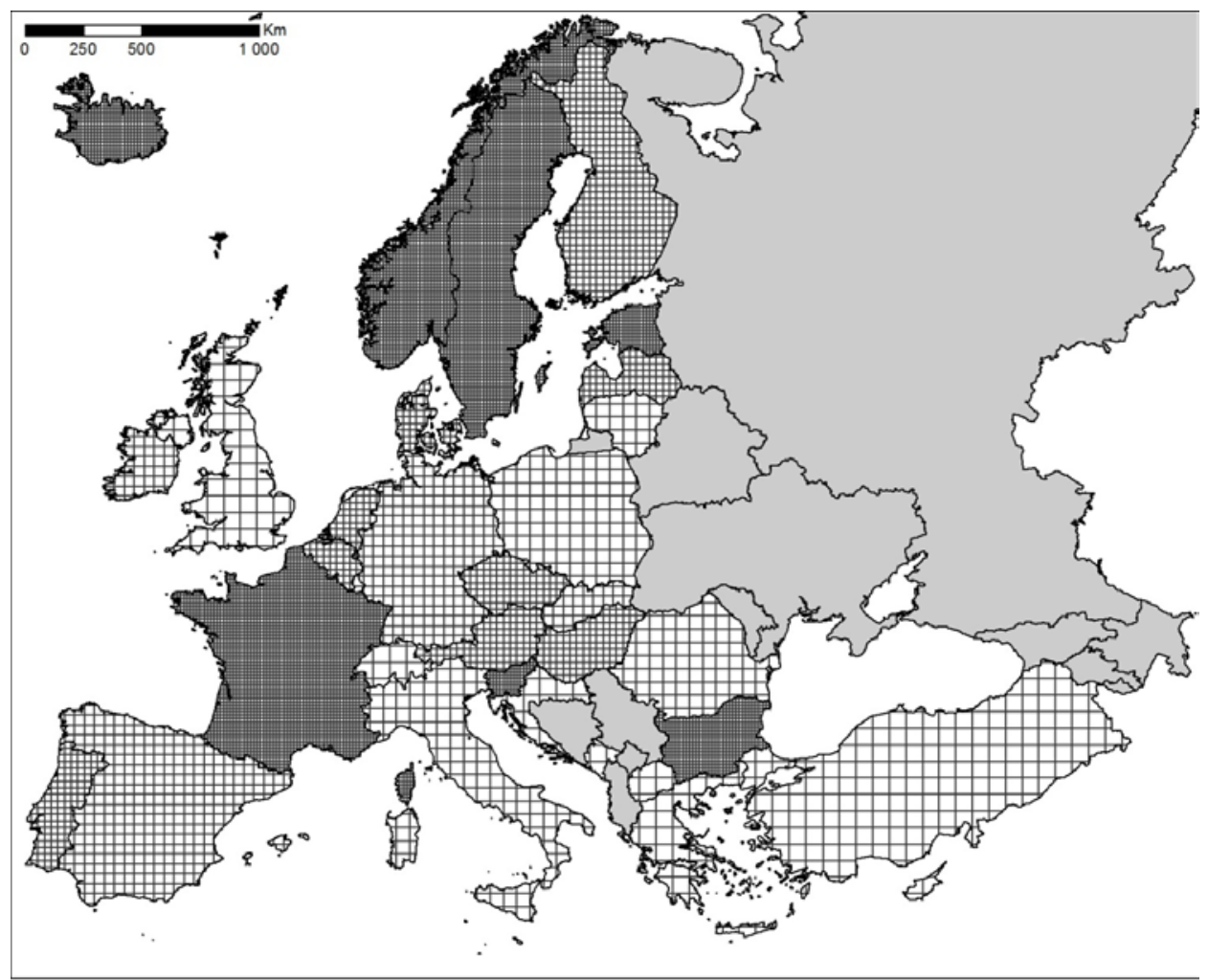

Proportion of live births outsider marriage

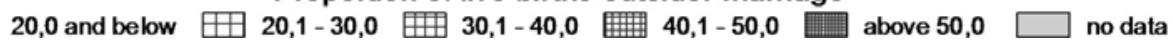

Fig. 6. Non-marital births (\%) in European countries in 2011

Source: Eurostat, http://epp.eurostat.ec.europa.eu/portal/page/portal/population/ data/database 
Total fertility rate of European women is one of the hallmarks of the changes in reproductive behaviours (Kurczewska 2011). According to Eurostat, in 2011, no European country had a total fertility rate of more than 2.1 children per woman which means that demographic renewal did not exist. Ireland, Turkey and Iceland were closest to that value (2.05, 2.04 and 2.02 respectively). The lowest TFR values were recorded in post-communist countries, including Poland (Fig. 7). Apart from a decrease of TFR, researchers have observed within the changes of the Second Transition an increase of the average age of mothers who give births. Comparative analysis of even the smallest time period, i.e. 20022011, indicated a delay in deciding about procreation by two or almost two years (Estonia, Lithuania, Slovakia, Bulgaria, the Czech Republic). The oldest mothers giving birth in Europe in terms of their average age are women in Ireland, Spain and Italy (Fig. 8).

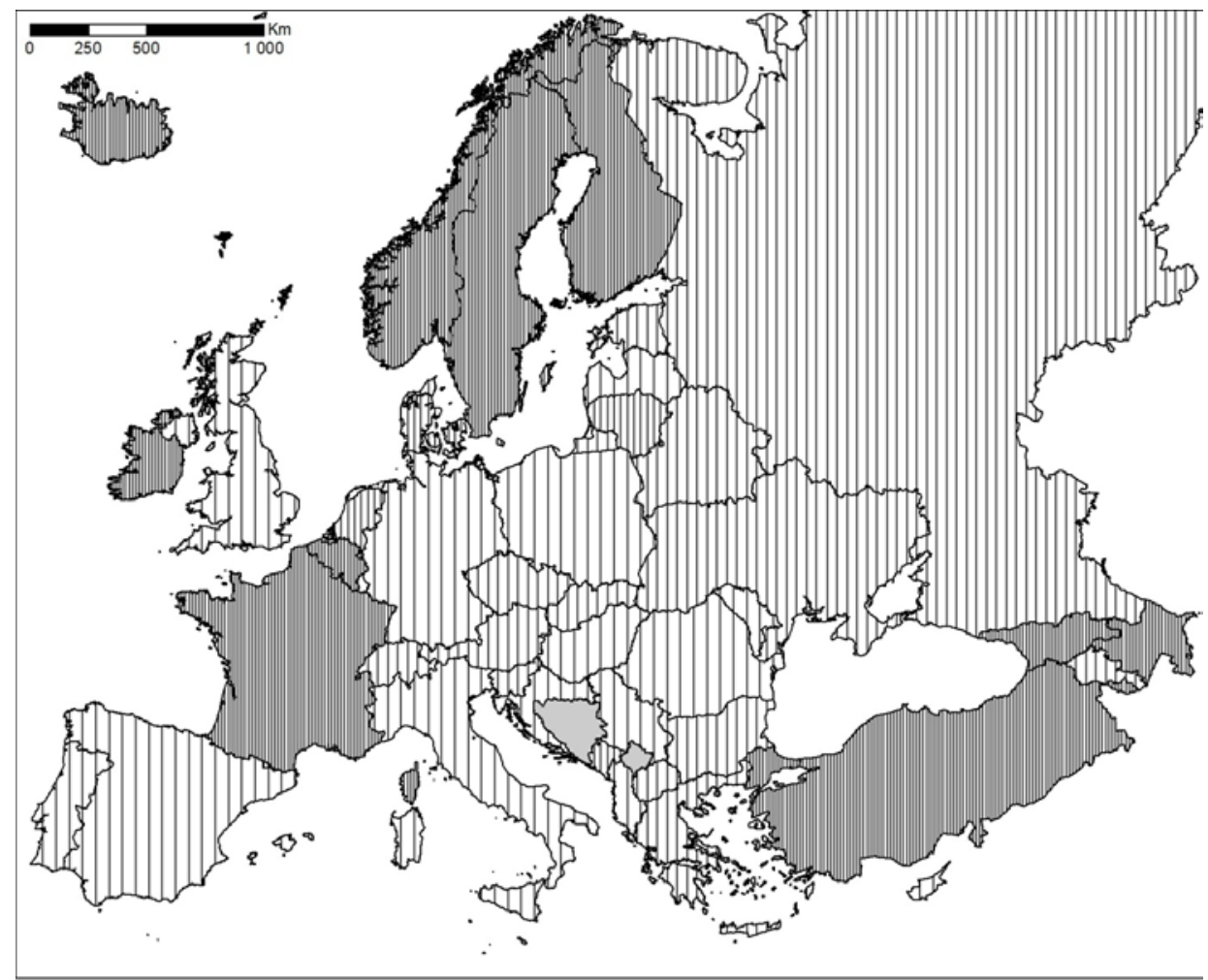

Total fertility rate

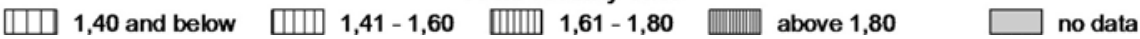

Fig. 7. Total fertility rate in European countries in 2011

Source: Eurostat, http://epp.eurostat.ec.europa.eu/portal/page/portal/population/ data/database 


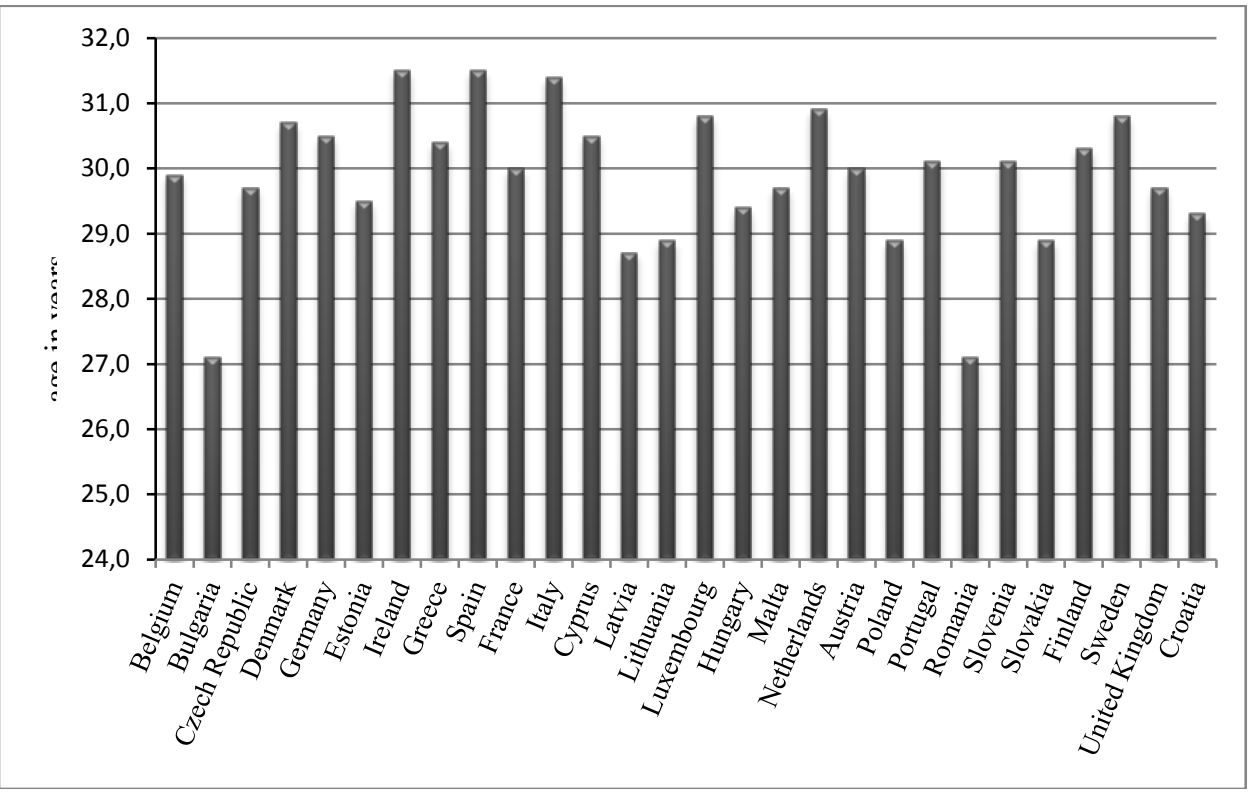

Fig. 8. Average age of women giving birth in selected European countries in 2011

Source: Eurostat, http://epp.eurostat.ec.europa.eu/portal/page/portal/population/ data/database

\subsection{CONCLUSIONS}

Through the analysis of selected indicators related to the changes to nuptiality and procreation in Europe, I intended to define the tendencies in demographic behaviour of Europeans. After several decades, the demographic changes which began in Northern and Western Europe reached the rest of the continent. In Central and Eastern European countries, the course of the process was short but exceptionally dynamic. It is those countries which suffer from a demographic crisis the main reasons of which are profound changes to the creation and breakdown of the family. I confirmed this through the analysis of the available statistical data. It offered an extremely spatially diverse image of Europe in terms of matrimonial and reproductive changes. The old political division of Europe into East and West took on a rather different shape and is no longer a result of ideology but of demographics. And new depopulation processes which mostly inflict post-communist countries are its direct consequence. 


\section{BIBLIOGRAPHY}

Auszug aus dem Datenreport 2011. Bevölkerung, http://www.destatis.de/DE/Publikationen/Datenreport/DatenreportDownload.html.

Eurostat, http://epp.eurostat.ec.europa.eu/portal/page/portal/population/data/database.

Kotowska I.E., 1998, Teoria drugiego przejścia demograficznego a przemiany demograficzne w Polsce w latach 1990., „Studia Demograficzne”, nr 4 (134).

Kurczewska U., 2011, Czy Unia Europejska może przezwyciężý pogłębiający się deficyt demograficzny? [w:] Osiński J. (red.), Współczesne problemy demograficzne. Rzeczywistość $i$ mity. Ujęcie krajowe, regionalne i globalne, Oficyna Wydawnicza SGH, Warszawa.

Kurkiewicz J., 1998, Podobieństwa i różnice przemian demograficznych krajów Europy Zachodniej i Środkowo-Wschodniej, „Studia Demograficzne”, nr 4 (134).

Okólski M., 2004, Demografia zmiany społecznej, Scholar, Warszawa.

Okólski M., 2005, Demografia. Podstawowe pojęcia, procesy $i$ teorie $w$ encyklopedycznym zarysie, Scholar, Warszawa.

Poselski projekt ustawy o zwiazkach partnerskich, druk nr 552, http://www.sejm.gov.pl/ Sejm7.nsf/druki.xsp\#7.

Raport Ewolucja rodziny w Europie 2009, http://pl.scribd.com/doc/22418149/ReportEvolution-on-the-Family-in-Europe-2009.

Rosset E., 1975, Demografia Polski, PWN, Warszawa.

Siewierski J., 2011, Europejskie wzorce kulturowe a procesy demograficzne [w:] Osiński J. (red.), Współczesne problemy demograficzne. Rzeczywistość i mity. Ujęcie krajowe, regionalne i globalne, Oficyna Wydawnicza SGH, Warszawa.

Sobotka T., Touleman L., 2008, Changing family and partnership behavior: Common trends and persistent diversity across Europe, "Demographic Research”, vol. 19, www. demographic-research.org/Volumes/Vol19/6/.

World Population Prospect. The 2010 Revision, New York, 2011, http://esa.un.org/wpp/ Documentation/publications.htm.

Yearbook Demographic 2011, 2012, United Nations, New York, http://unstats.un.org/ unsd/demographic/products/dyb/dyb2.htm.

\section{STRESZCZENIE}

\section{DRUgIE PRZEJŚCIE DEMOGRAFICZNE W EUROPIE I JEGo IMPLIKACJE}

Celem artykułu jest przedstawienie wybranych przemian demograficznych w krajach europejskich dotyczących drugiego przejścia demograficznego. W opracowaniu zaprezentowano wybrane charakterystyki demograficzne dla krajów europejskich i ich przestrzenne zróżnicowanie. Biorąc pod uwagę wybrane wskaźniki ilościowe dokonano porównania przebiegu zmian demograficznych w krajach europejskich według długoletniego politycznego podziału Europy na Wschód i Zachód. Przemiany demograficzne, które rozpoczęły się w Europie Północnej i Zachodniej po kilku- 
dziesięciu latach objęły pozostałe części kontynentu. W krajach wschodnioi środkowoeuropejskich przebieg tych procesów był krótki, ale niezwykle dynamiczny. Właśnie tam obserwujemy kryzys demograficzny, u którego podłoża leżą głębokie przemiany tworzenia i rozpadu rodziny. Potwierdziła to analiza dostępnych materiałów statystycznych. Wynika z niej obraz bardzo zróżnicowanej przestrzennie Europy pod względem przemian matrymonialno-reprodukcyjnych. Dawny podział polityczny Europy na Wschód i Zachód, dziś ma inny wymiar i jest to efekt już nie ideologiczny, a demograficzny. Bezpośrednią implikacją tego stanu rzeczy są rozpoczęte procesy depopulacyjne, które w największym stopniu dotykają krajów postkomunistycznych.

Dr Anna Janiszewska

Katedra Gospodarki Przestrzennej i Planowania Przestrzennego

Wydział Nauk Geograficznych, Uniwersytet Łódzki 